\title{
Can Corrupt Countries Attract Foreign Direct Investment? A Comparison Of FDI Inflows Between Corrupt And Non-Corrupt Countries
}

Michael J. Harrison (E-mail: MJHarrison1@msn.com), Southern New Hampshire University

\begin{abstract}
Globalization and technological innovations create investment opportunities for enterprises worldwide. While firms pursue foreign direct investment opportunities on a global basis, countries compete to attract foreign direct investment (FDI) inflows. Recent studies suggest that corruption negatively impacts FDI inflows and may act as a "tax" on foreign direct investment. Transparency International, a non-profit organization, publishes an annual index measuring the "perceived" level of corruption in countries all over the world. Countries competing for FDI inflows are ranked from least-corrupt to most-corrupt. This paper analyses FDI inflows between the least corrupt and most corrupt countries as determined by Transparency International's Corruption Perceptions Index. Using UNCTAD's Inward FDI Potential Index and Inward FDI Performance Index this paper assesses and draws conclusions regarding the absolute amount of FDI inflows, FDI inflows adjusted for country size, and FDI inflow potential.
\end{abstract}

\section{Introduction}

lobalization and technological innovations create investment opportunities for enterprises worldwide. Foreign Direct Investment (FDI) is one investment option firms choose when expanding into international markets. Firms pursuing international business opportunities analyze a number of factors regarding the FDI location decision (Dunning, 199, Porter, 2000). At the same time, countries compete to attract foreign firm's FDI inflows. One competing factor receiving increased attention in international business is a country's level of corruption. Media attention, academic studies, and international agreements are increasingly focused on corruption. Transparency International, a not-for-profit agency established in 1993, annually compares country corruption and provides a Corruption Perception Index (CPI) ranking to the public through its web site. The level of corruption for countries competing for FDI inflows are readily available for potential foreign business investors to compare. Analyzing the FDI inflows of the 20 least-corrupt and the 20 most-corrupt countries provides a basis for determining the relationship between FDI inflows and a country's level of corruption. With the increased focus on corruption the analyses will answer the question, "Can corrupt countries attract FDI inflows?"

\section{Literature Review}

Mauro (1995) determined that there is a negative association between corruption and investment as well as growth. A one-standard-deviation increase in the corruption index will generate an increase in the investment rate of $2.9 \%$ of GDP. Thus, the impact of corruption on investment is significant. Wei (2000) found that corruption acts

$\overline{\text { Readers with comments }}$ or questions are encouraged to contact the author via email. 
like a tax and its impact of FDI inflows can be measured as such. Comparing corruption levels between Singapore and Mexico, Wei (2000) concludes that raising the index of corruption from the Singapore level to the Mexican level is equivalent to raising the marginal tax rate on enterprises by 50 percentage points. Goldsmith (1999) indicates that the new consensus view of corruption is that it stunts economic growth. The Economist Intelligence Unit (2002) asserts that corruption's damaging impact can not be underestimated and that there is clear evidence that it deters investment.

FDI location is driven by the search for markets, resources, efficiency, and strategic assets (Dunning, 1998). The literature supports the notion that corrupt countries would have difficulty attracting FDI inflows based upon their level of corruption. This paper attempts to answer the question, "Can corrupt countries attract FDI?"

\section{Methodology}

Using Transparency International's Corruption Perceptions Index (CPI), as a proxy for corruption level, and the United Nations Conference on Trade and Development's Inward FDI Performance Index, FDI inflows for the 20 least-corrupt and the 20 most-corrupt countries are analyzed. Wilhelm (2002) validates the CPI as a proxy for corruption. The annual CPI score for the 20 least-corrupt and 20 most-corrupt countries for 1998, 1999 and 2000 are compared with UNCTAD's 1998-2000 Inward FDI Performance Index. The UNCTAD index is a composite for the three years. The Inward Performance Index yields a single number for the three year period. Additionally, UNCTAD's Inward FDI Potential Index is used to compare the least and most corrupt countries to determine where each country falls on a high/low performance/potential matrix.

The least-corrupt countries included in this study all ranked in the top 20 of Transparency International's annual CPI Index for the years 1998, 1999, and 2000. The CPI ranked 85 countries in 1998, 99 countries in 1999 and 90 countries in 2000 . Within the three year time period, the rank order of the countries differed in the annual results even though all remained in the top 20. For the purpose of this paper, the corruption rank order for the most and least corrupt 20 countries are based on the 2000 CPI results.

UNCTAD's 1998-2000 Inward FDI Performance Index scores and ranks 140 countries for the three year period by comparing each country's FDI and Gross Domestic Product (GDP). The index is the ratio of a country's share in global FDI flows to its share in global GDP (WIR 2001, p. 23). The mathematical formula is:

$$
I N D_{i}=\frac{F D I_{i} / F D I_{w}}{G D P_{i} / G D P_{w}}
$$

Where,

$$
\begin{aligned}
& \text { INDi }=\text { The inward FDI Performance Index of the } \mathrm{i}^{\text {th }} \text { country } \\
& \mathrm{FDI}_{\mathrm{i}}=\text { FDI inflows in the } \mathrm{i}^{\text {th }} \text { country } \\
& \mathrm{FDI}_{\mathrm{w}}=\text { World FDI inflows } \\
& \mathrm{GDP}_{\mathrm{i}}=\text { GDP in the } \mathrm{i}^{\mathrm{th}} \text { country } \\
& \mathrm{GDP}_{\mathrm{w}}=\text { World GDP }
\end{aligned}
$$

Therefore, if a country's share in global FDI flows matches its relative share in global GDP the country's Inward FDI Performance Index would be one. A score greater than one indicates a larger share of FDI relative to GDP and a score less than one indicates a smaller share of FDI relative to GDP. Using UNCTAD's Inward FDI Performance Index provides a relative measure to compare both corrupt and non-corrupt wealthy, large market countries to less developed, smaller market corrupt and non-corrupt countries.

UNCTAD's Inward FDI Potential Index assesses each country's attractiveness for FDI inflows based on eight variables. The eight variables are: GDP per capita, real GDP growth for the past ten years, exports as a percentage of GDP, number of telephone lines per 1000 inhabitants, commercial energy use per capita, R\&D 
expenditures as a percentage of gross national income, students in tertiary education as a percentage of total population, and political risk. The mathematical formula is:

Score $=\frac{V_{i}-V_{\text {min }}}{V}$

$$
V_{\max }-V_{\min }
$$

Where,

$V_{i}=$ the value of a variable for country $i$

$\mathrm{V}_{\min }=$ the lowest value of a variable among the countries

$\mathrm{V}_{\max }=$ the highest value of a variable among the countries

\section{Results}

Comparing the level of corruption and level of FDI inflows among the 20 least-corrupt countries for the years 1998-2000 reveals that the United States received the largest amount in each of the three years followed by Belgium/Luxembourg and the United Kingdom. The amount of FDI inflows and level of corruption do not indicate a strong correlation. Figure 1 displays the results and ranks the 20 least-corrupt countries in order of there 2000 CPI Index placement.

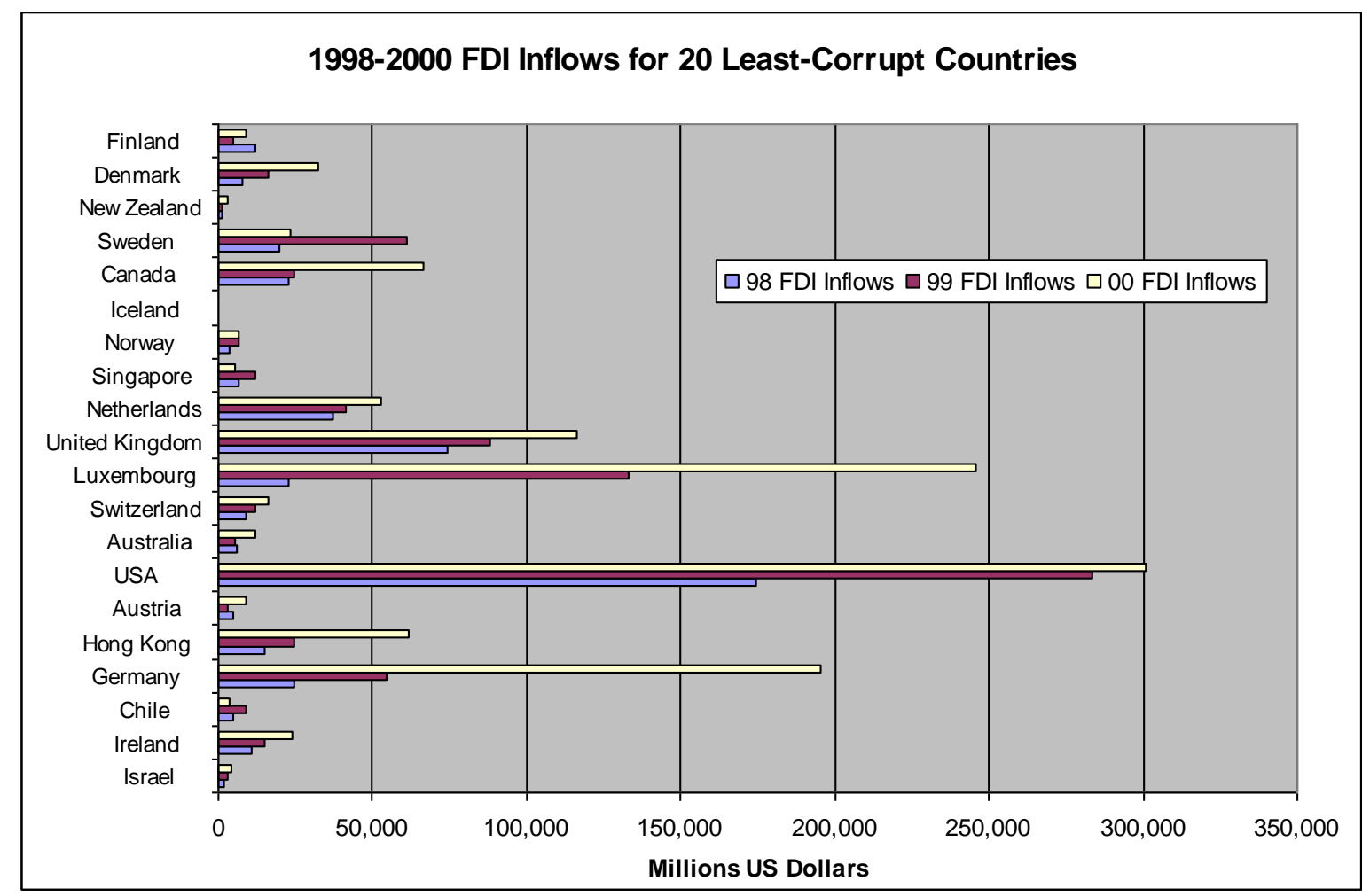

Figure 1. Source: UNCTAD Online FDI Database

Note: Luxembourg figures include Belgium

Comparing the level of corruption and level of FDI inflows among the 20 most-corrupt countries reveals that Nigeria, Ukraine, and Azerbaijan, the three most-corrupt countries, received positive FDI inflows in each of the three years while Indonesia, the fourth most-corrupt country, was the only country in the study that sustained 
negative inflows. The negative inflows occurred in each of the three years from 1998-2000. The amount of FDI inflows and level of corruption among the 20 most-corrupt countries do not indicate a strong correlation. Figure 2 displays FDI inflows for the 20 most-corrupt countries for the years 1998-2000.

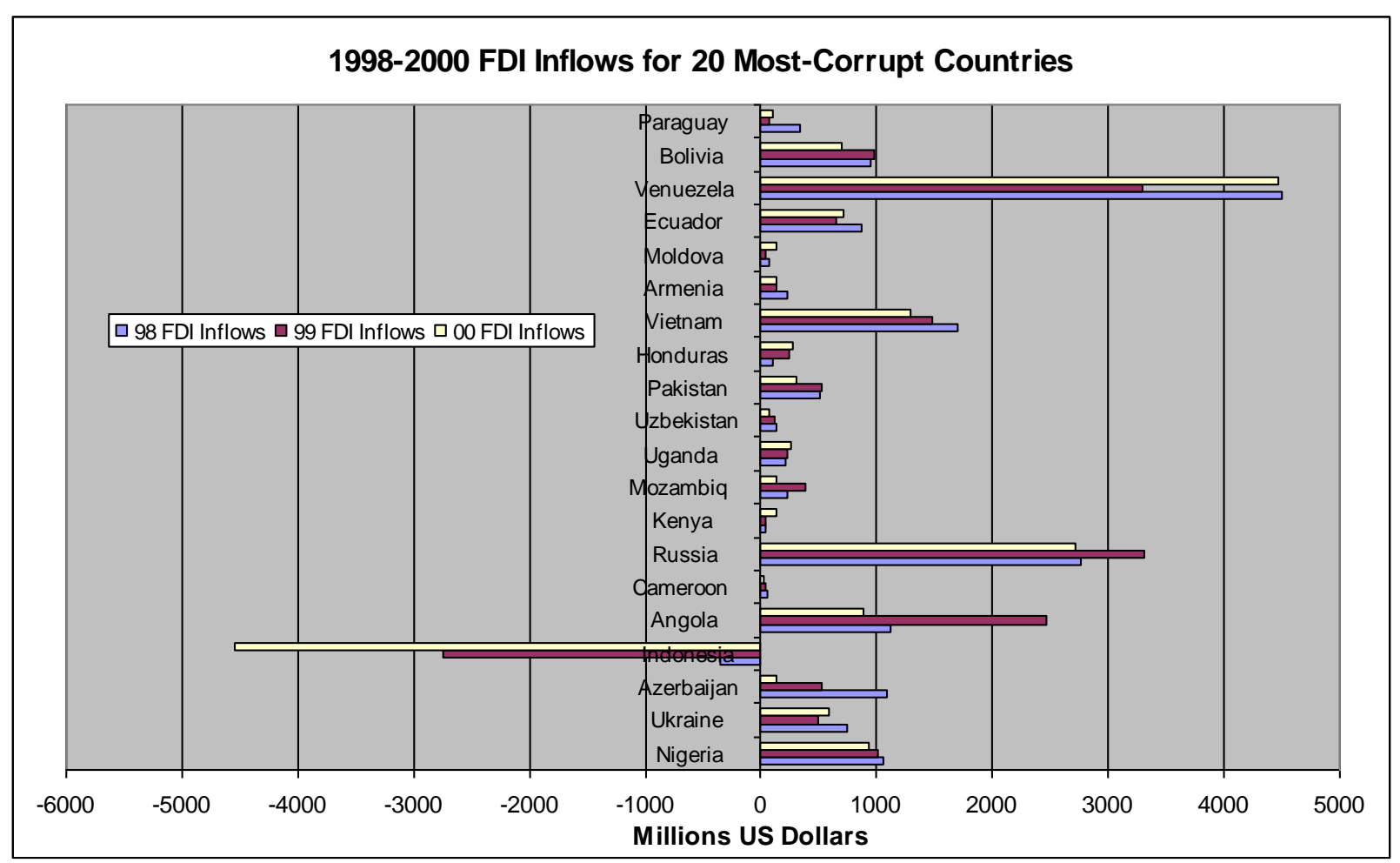

Figure 2. Source: UNCTAD Online FDI Database

Note: Uzbekistan and Cameroon FDI inflows are estimates. Tanzania and Yugoslavia were omitted due to lack of inclusion in UNCTAD data. Angola and Moldova replace Tanzania and Yugoslavia based on their 2000 CPI rank.

A comparison of the inward FDI flows between the 20 least-corrupt countries and the 20 most-corrupt countries reveals a significant difference in the absolute amount of FDI flows. The United States attracted over $\$ 174.4$ billion, $\$ 283.6$ billion and $\$ 300.9$ billion is each of three years respectively. The average amount of FDI inflows for the 20 least-corrupt countries over the three year period was more than $\$ 22.9$ billion, $\$ 39.9$ billion and $\$ 59.3$ billion respectively.

The average FDI inflow among the 20 most-corrupt countries was $\$ 817$ million, $\$ 663$ million and $\$ 472$ million respectively over the three year period. The 20 least-corrupt countries clearly attract a significantly larger share of FDI inflows compared to the 20 most-corrupt countries. In each of the three years, Venezuela, a member of the 20 most-corrupt countries, attracted more FDI inflows than four members of the 20 least-corrupt group. Nigeria, the most-corrupt country, attracted more FDI inflows than $6^{\text {th }}$ ranked Iceland in each of the three years. 


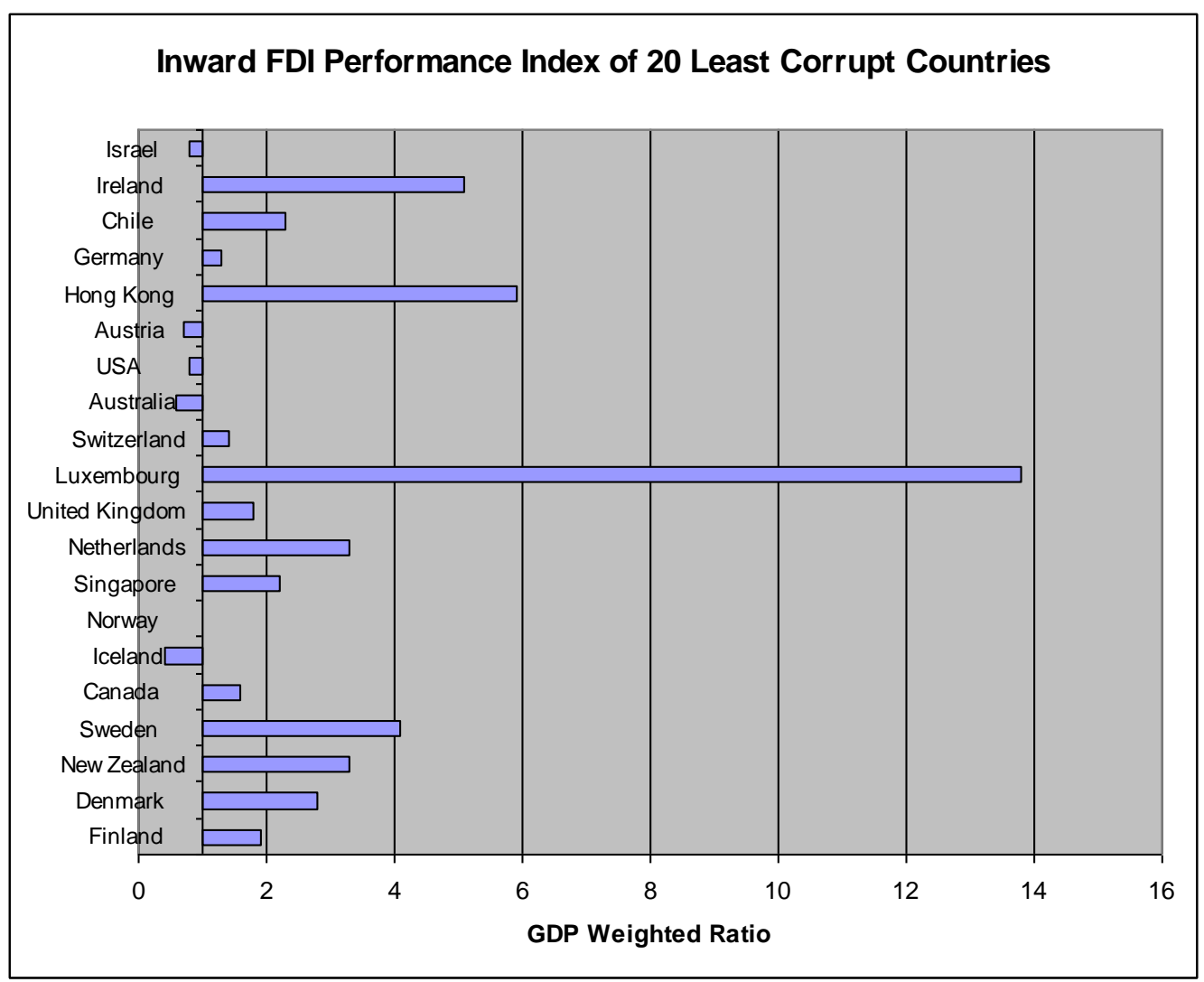

Figure 3. Source: UNCTAD's 2002 World Investment Report Note: Luxembourg figures include Belgium

Comparing the FDI inflows of the 20 least-corrupt countries relative to their GDP reveals a vastly different view of FDI performance. While the United States, Belgium/Luxembourg and the United Kingdom attracted the largest amount of FDI inflows, the GDP adjusted performance measure reveals Belgium/Luxembourg, Hong Kong and Ireland performed better than the United States and the United Kingdom on a relative basis. The United States, adjusted for GDP, attracted less FDI inflows than its size warrants. In total, five of the 20 least-corrupt countries did not attract FDI inflows significant enough to match their GDP adjusted ratio.

Nine of the 20 most-corrupt countries attracted more FDI inflows than their GDP adjusted ratio suggests while two countries, Honduras and Uganda attracted FDI inflows equal to their relative GDP. Angola attracted over five times the amount suggested by its relative size. Azerbaijan attracted over three times while Bolivia attracted exactly three times the amount of FDI inflows expected based on its relative GDP. Figure 4 displays the Inward FDI Performance results of the 20 most-corrupt countries.

Comparing the Inward FDI Potential Index scores of the 20 least-corrupt and 20 most-corrupt countries demonstrates a clear difference between the two groups. The 20 least-corrupt countries Inward FDI Potential scores were significantly greater than the 20 most-corrupt countries. The trend is displayed in Figure 5. 


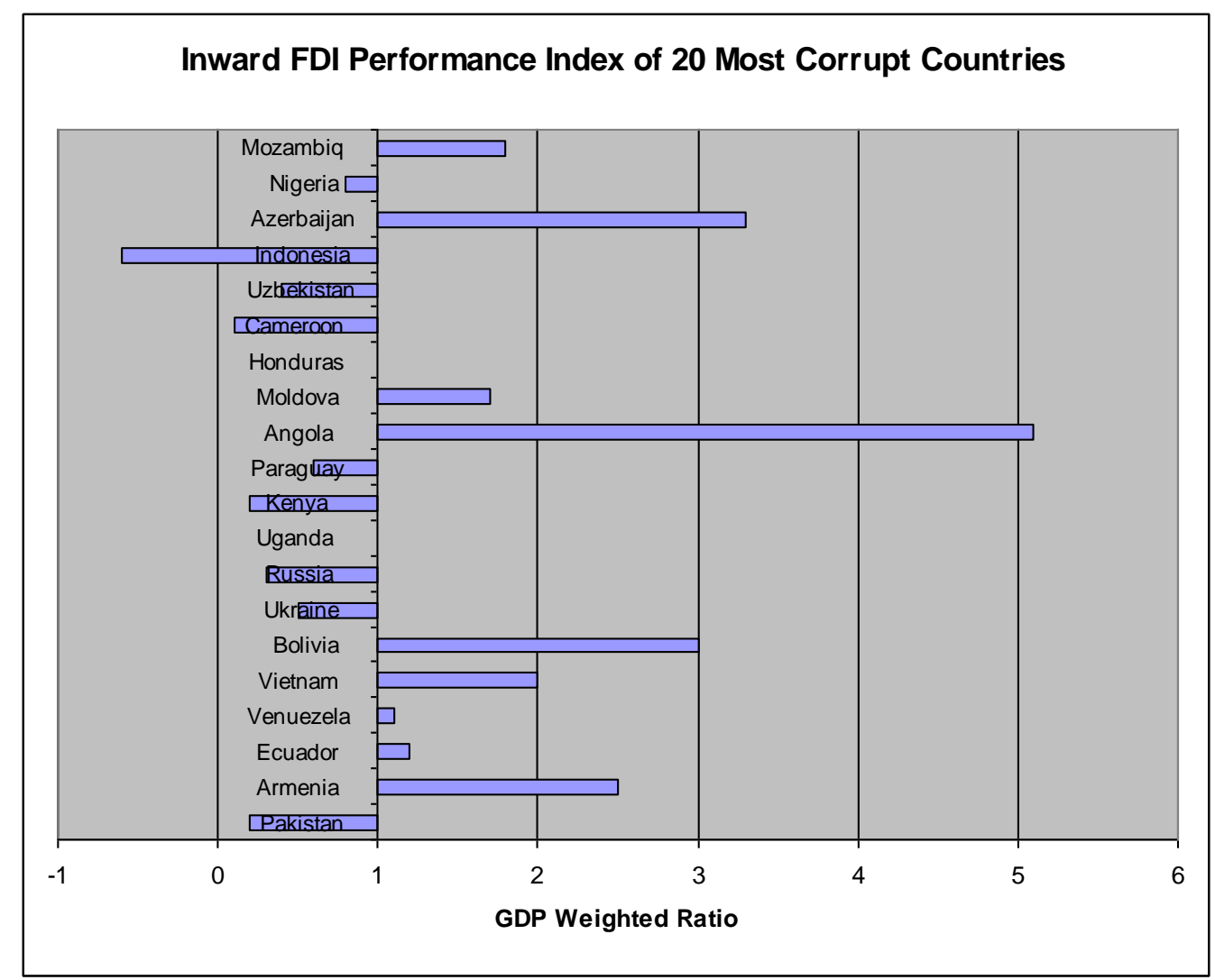

Figure 4. Source: UNCTAD's 2002 World Investment Report

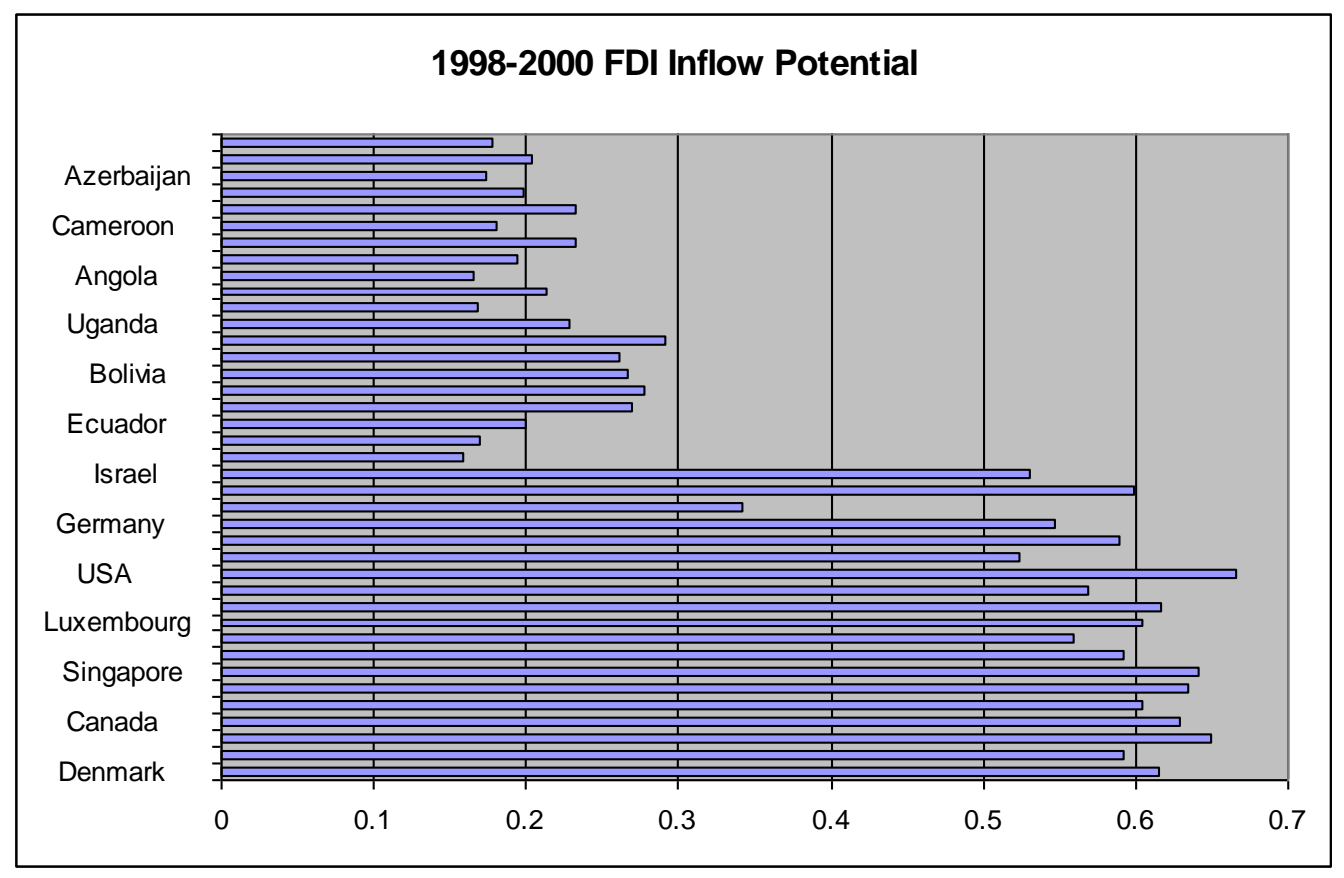

Figure 5. Source: UNCTAD's 2002 World Investment Report 
Categorizing the 20 least-corrupt and 20 most-corrupt countries into a high/low performance/potential matrix reveals interesting results. UNCTAD categorizes "High FDI Potential" for any country scoring above the mid-point of all 140 countries included in the Inward FDI Potential Index. Four of the 20 least-corrupt countries, Australia, Austria, Iceland and the United States, fall into the high FDI potential and low FDI performance category. Even though the United States attracted the largest amount of FDI inflows in each of the three years studied, its performance, on a relative basis was low. On a relative basis, nine of the 20 most-corrupt countries attracted more FDI than their country size warranted while two, Honduras and Uganda attracted inflows exactly relative to their global GDP ratio.

\begin{tabular}{|l|l|l|}
\cline { 2 - 3 } \multicolumn{1}{c|}{ High FDI } & \multicolumn{1}{c|}{ High FDI Performance } & \multicolumn{1}{c|}{ Low FDI Performance } \\
\hline Potential & $\begin{array}{l}\text { Canada, Chile, Denmark, Finland, Germany, } \\
\text { Hong Kong, Ireland, Israel, Luxembourg, } \\
\text { Netherlands, New Zealand, Norway, Singapore, } \\
\text { Sweden, Switzerland, United Kingdom }\end{array}$ & $\begin{array}{l}\text { Australia, Austria, Iceland } \\
\text { Russia, United States }\end{array}$ \\
\hline $\begin{array}{l}\text { Low FDI } \\
\text { Potential }\end{array}$ & $\begin{array}{l}\text { Angola, Armenia, Azerbaijan, Bolivia, Ecuador, } \\
\text { Honduras, Moldova, Mozambique, Uganda, } \\
\text { Venezuela, Vietnam }\end{array}$ & $\begin{array}{l}\text { Cameroon, Indonesia, } \\
\text { Kenya, Nigeria, Pakistan, } \\
\text { Paraguay, Ukraine, } \\
\text { Uzbekistan }\end{array}$ \\
\hline
\end{tabular}

Table 1. Source: UNCTAD’s 2002 World Investment Report

\section{Limitations}

Limitations of this study include the duration and matching of the available data. UNCTAD's Inward FDI Performance Index and Inward FDI Potential Index scores are available for two time period intervals. One interval is for 1988-1990 and the other interval is for 1998-2000. Transparency International's Corruption Perceptions Index annual scores are available for each year from 1995-2002. The analysis covers a three year time period and uses annual FDI inflow and corruption data while the FDI performance and potential data is a composite score for the same three year time period. As UNCTAD and Transparency International continue to produce reports over time, further analysis utilizing a larger sample size is appropriate. Also, FDI inflows are only one measure of FDI. Merger and acquisition activity, which can account for a significant amount of FDI, is not included in this study.

\section{Conclusion}

Overall the least-corrupt countries attract a significantly lager amount of FDI inflows compared to the most-corrupt countries. Sixteen out of the 20 least-corrupt countries outperformed based on the FDI Performance Index while eleven out of the 20 most-corrupt countries outperformed based on the FDI Performance Index. This supports the argument that corrupt countries can attract FDI inflows. Nineteen of the 20 most-corrupt countries fall into the low potential category. Corrupt countries' attractiveness for FDI inflows warrants scrutiny by potential investors and by the country leaders.

Low growth, minimal exports, lack of telecommunications and energy infrastructure, minimal R\&D expenditures, low education level and political risk characterize the low potential countries. The analysis suggests that corruption is significantly correlated with low inward FDI potential. However, 11 out of 19 most-corrupt, low potential countries attracted FDI inflows greater than anticipated based on UNCTAD's Inward FDI Performance Index. This leads to the question, why are certain corrupt, low potential countries able to attract FDI inflows and others not? 


\section{Implications for Further Research}

While government and non-governmental agencies pressure countries to reduce corruption, business enterprises continue to seek new opportunities. Corruption may never be fully neutralized. Therefore, it is appropriate to investigate why corrupt countries are able to attract FDI inflows and how firms approach the corruption problem. Further analysis of why certain low potential, highly corrupt countries attract inward FDI inflows and why other low potential, highly corrupt countries do not, is a topic for consideration. The absolute amount of FDI inflows that most-corrupt countries attract is significantly lower than least-corrupt countries. Low volume coupled with low potential, based on UNCTAD's eight potential variables, may be an area of interest to researchers and firms involved in telecommunications, energy, and infrastructure development.

\section{References}

1. Dunning, J. (1998). The Eclectic Paradigm of International Production: A Restatement and Some Possible Extensions. Journal of International Business Studies, 19, (Spring): 1-31.

2. 1998. Location and the Multinational Enterprise: A Neglected Factor? Journal of International Business Studies, 29, (1): 45-66.

3. The Economist Intelligence Unit. (2002, Sept. 16). The Cost of Corruption. Business Africa, 11, (17) 1.

4. Goldsmith, A., A. (1999). Slapping the Grasping Hand: Correlates of Political Corruption in Emerging Markets. American Journal of Economic and Sociology, 58, (4) 865-883.

5. Mauro, P. 1995. Corruption and Growth. The Journal of Quarterly Economics, August: 686-706.

6. Porter, M. 2000. Location, Competition, and Economic Development: Local Clusters in a Global Economy. Economic Development Quarterly, 14, (1) 15-35.

7. Transparency International. (1998). The Corruption Perceptions Index (1998) [On-line]. Available: http://www.transparency.org/cpi/1998/cpi1998.html.

8. _ _ (1999). 1999 Corruption Perceptions Index [On-line]. Available: http://www.transparency.org/ cpi/1999/cpi1999.html.

9. _. (2000). The 2000 Corruption Perceptions Index [On-line]. Available: http://www.transparency.org/ cpi/2000/cpi2000.html.

10. United Nations Conference on Trade And Development. Division on Investment, Technology, and Enterprise Development. 2002 World Investment Report [on-line]. Available: www.UNCTAD.org/ Statistics / Statistical Databases / Foreign Direct Investment / World Investment Directory On-line / WIR.

11. Wei, S., J. (2000). How Taxing is Corruption on International Investors? Review of Economics and Statistics, 82, 1-11

12. Wilhelm, G. P. (2002). International Validation of the Corruption Perceptions Index: Implications for Business Ethics and Entrepreneurship Education. Journal of Business Ethics, 35, (3) 177-189. 